\title{
Regulation of Amino Acid Intake in the Rat: Self-Selection of Methionine and Lysine
}

\author{
Keiichiro MURAmatsu and Masahiro ISHIDA ${ }^{1}$ \\ Department of Agricultural Chemistry, Faculty of Agriculture, \\ Shizuoka University, Shizuoka 836, Japan
}

(Received August 10, 1981)

\begin{abstract}
Summary A study was undertaken to measure the ability of rats to regulate amino acid intake by means of a self-selection method. Weanling rats were simultaneously offered a choice between a $10 \%$ casein diet or a $10 \%$ amino acid mixture diet lacking methionine or lysine and a $10 \%$ casein diet containing different levels of methionine or lysine over 2 weeks. Weight gain and food consumption of rats allowed a choice between the two diets were much greater than those of animals fed on the fixed diets with high levels of methionine or lysine added, and the self-selecting rats had the ability to take in amounts of methionine or lysine appropriate to meet the requirement. Methionine intakes of self-selecting rats were kept to a relatively narrow range (41-100 $\mathrm{mg}$ /day), but lysine intakes of selfselecting rats were wide-ranging $(86-300 \mathrm{mg} /$ day). It was demonstrated that methionine or lysine intake is closely regulated in rats given a choice of diets containing varied levels of methionine or lysine.

Key Words methionine, lysine, self-selection, intake regulation, weanling rats
\end{abstract}

It is well known that growth and food intake are depressed in rats fed on a lowprotein diet containing excessive levels of many individual amino acids (1-4). Methionine has been confirmed to be the most toxic of the amino acids that constitute protein, on a weight basis $(1-3)$. The addition of $2 \%$ or more of methionine to low-protein diets results in a decrease in growth and food intake $(1,3)$ and morphologic alterations of several tissues (5-7). In contrast, the high levels of lysine produce effects much less depressing than with methionine $(1-3,8,9)$. In any case, decreased food intake in rats fed on diets which have high levels of amino acids added might be primarily responsible for growth depression. Most of these studies have been done in animals fed on only one diet with a fixed content of high amino acid, i.e. fixed-ratio diet.

A self-selection method in which animals were simultaneously offered a choice

\footnotetext{
${ }^{1}$ 村松敬一郎, 石田真裕
} 
of two diets which differed only in amino acid content would provide a useful technique for examining the relationship between food intake and amino acid ingestion. A feeding system of this type has been used for studies of food preference with regard to protein (10-15), and amino acid disproportion $(1,15-20)$, but little information is available on the effect of varied levels of amino acids on food intake.

The present investigation was designed to determine the effects of different levels of amino acids, methionine or lysine, on food preference in the weanling rat.

\section{METHODS}

Male weanling rats $(35-40 \mathrm{~g})$ of the Wistar strain were individually housed in suspended wire-bottomed cages and were kept in an air-conditioned room $\left(24 \pm 1^{\circ} \mathrm{C}\right)$ with a light period lasting from 8:00 to 18:00. All rats were fed on a stock diet ( $25 \%$ casein) for the 3 or 4 days before the experiments. Animals weighing 55 to $60 \mathrm{~g}$ were divided into two experimental series and separated into several groups of five rats each.

The composition of the basal diet was as follows $(\%)$ : casein, 10.0 ; soybean oil, 5.0; salt mixture, 5.0; vitamin mixture, 1.0; choline chloride, 0.1 ; and $\alpha$-potato starch, $78.9(21)$. Vitamin $\mathrm{A}(2,000 \mathrm{IU})$ and $\mathrm{D}_{2}(200 \mathrm{IU})$ were also added (21). Graded levels of amino acid ( $\mathrm{L}$-methionine or L-lysine $\cdot \mathrm{HCl}$ ) were added to the basal diet at the expense of starch. Sulfur amino acid-devoid (10AA-S) and lysine-devoid (10AA-L) diets were also prepared on the basis of an amino acid mixture simulating casein. Each $100 \mathrm{~g}$ of the amino acid mixture diet contained the following amino acids (in $\mathrm{mg}$ ): L-arginine $\cdot \mathrm{HCl}, 427$, L-histidine $\cdot \mathrm{HCl} \cdot \mathrm{H}_{2} \mathrm{O}, 313$; L-lysine $\cdot \mathrm{HCl}, 863$; L-leucine, 844; L-isoleucine, 556; L-valine, 622; L-methionine, 290; L-cystine, 40; Lphenylalanine, 490; L-tyrosine, 531; L-tryptophan, 126; L-threonine, 379; glycine, 177; L-glutamic acid, 2,296; L-proline, 1,036; L-serine, 531; L-aspartic acid, 547; Lalanine, 262. The amino acid mixture with sulfur amino acids (methionine and cystine) or lysine absent was substituted for casein in the basal diet, and the diets were kept isonitrogenous by the addition of L-glutamic acid.

The experimental diets and water were provided ad libitum and the feeding period for all experiments was 2 weeks. Animals were weighed each morning. Food consumption was measured on a dry matter basis with correction for spillage. Ingested amounts of dietary methionine or lysine were calculated from the food consumed. When rats were offered a choice of diet, the location of the two food cups was changed daily to prevent any positional preference.

Experiment 1. In experiment 1-A, rats had access to only a single diet containing varied levels of methionine (fixed-ratio feeding). The dietary groups were the $10 \%$ casein diet $(10 \mathrm{C})$, the $10 \%$ casein diets containing $0.1,0.2,0.5,1.0,2.0$ and $5.0 \% \mathrm{~L}$-methionine $(10 \mathrm{C} 0.1 \mathrm{M}, 10 \mathrm{C} 0.2 \mathrm{M}, 10 \mathrm{C} 0.5 \mathrm{M}, 10 \mathrm{C} 1 \mathrm{M}, 10 \mathrm{C} 2 \mathrm{M}$ and $10 \mathrm{C} 5 \mathrm{M})$, and the amino acid mixture diet lacking methionine and cystine (10AA-S).

In experiment $1-\mathrm{B}$, rats were offered a choice between the $10 \mathrm{C}$ and the $10 \mathrm{C} 0.1 \mathrm{M}, 10 \mathrm{C} 0.2 \mathrm{M}, 10 \mathrm{C} 0.5 \mathrm{M}, 10 \mathrm{C} 1 \mathrm{M}, 10 \mathrm{C} 2 \mathrm{M}$ or $10 \mathrm{C} 5 \mathrm{M}$ diets, and were given 
the choice between the 10AA-S and the 10C1M diets (self-selection feeding).

Experiment 2. In experiment 2-A, rats were fixed-ratio fed on the $10 \%$ casein diet $(10 \mathrm{C})$, the $10 \%$ casein diet containing 1.0, 3.0, 5.0 and $7.0 \% \mathrm{~L}-l y s i n e \cdot \mathrm{HCl}$ $(10 \mathrm{C} 1 \mathrm{~L}, 10 \mathrm{C} 3 \mathrm{~L}, 10 \mathrm{C} 5 \mathrm{~L}$ and $10 \mathrm{C} 7 \mathrm{~L})$ and the amino acid mixture diet lacking lysine (10AA-L).

In experiment $2-\mathrm{B}$, rats were offered a choice between the $10 \mathrm{C}$ and the $10 \mathrm{C} 1 \mathrm{~L}$, $10 \mathrm{C} 3 \mathrm{~L}, 10 \mathrm{C} 5 \mathrm{~L}$ or $10 \mathrm{C} 7 \mathrm{~L}$ diets, and were also separately fed on the $10 \mathrm{AA}-\mathrm{L}$ and the $10 \mathrm{C}, 10 \mathrm{C} 1 \mathrm{~L}$ or $10 \mathrm{C} 5 \mathrm{~L}$ diet.

\section{RESULTS}

\section{Experiment 1}

The effects of the feeding methods (fixed and self-selection) on weight gain, food consumption and methionine intake in rats given diets which differed in methionine content are presented in Table 1, and the changes in the daily food preference of rats offered two diets are shown in Fig. 1.

When rats were fed on the fixed-ratio diet (Exp. 1-A), the largest weight gain was observed in the animals consuming diets in which $0.1,0.2$ and $0.5 \%$ methionine
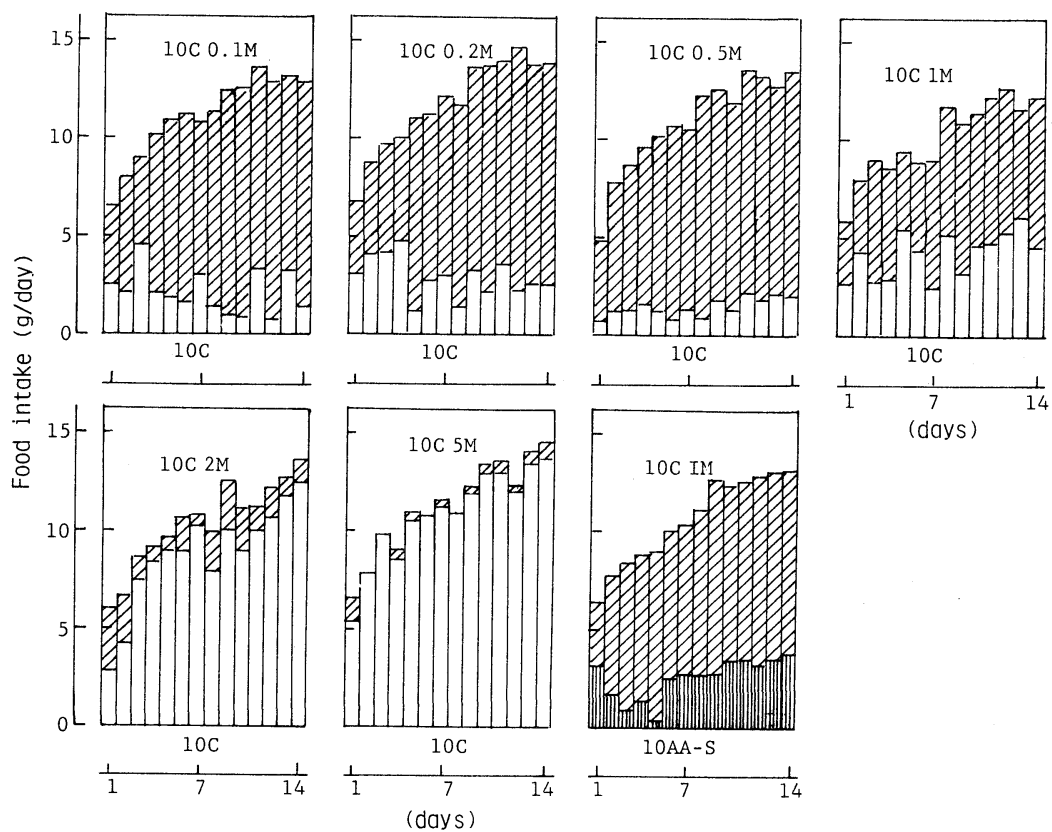

days

Fig. 1. Food preference in rats offered a choice of two diets differing in methionine content. Open bars $=10 \mathrm{C}$ group; hatched bars $=10 \mathrm{C} 0.1 \mathrm{M}, 10 \mathrm{C} 0.2 \mathrm{M}, 10 \mathrm{C} 0.5 \mathrm{M}$, $10 \mathrm{C} 1 \mathrm{M}, 10 \mathrm{C} 2 \mathrm{M}$ or $10 \mathrm{C} 5 \mathrm{M}$ groups; and vertical-stripe bars=10AA-S group. 


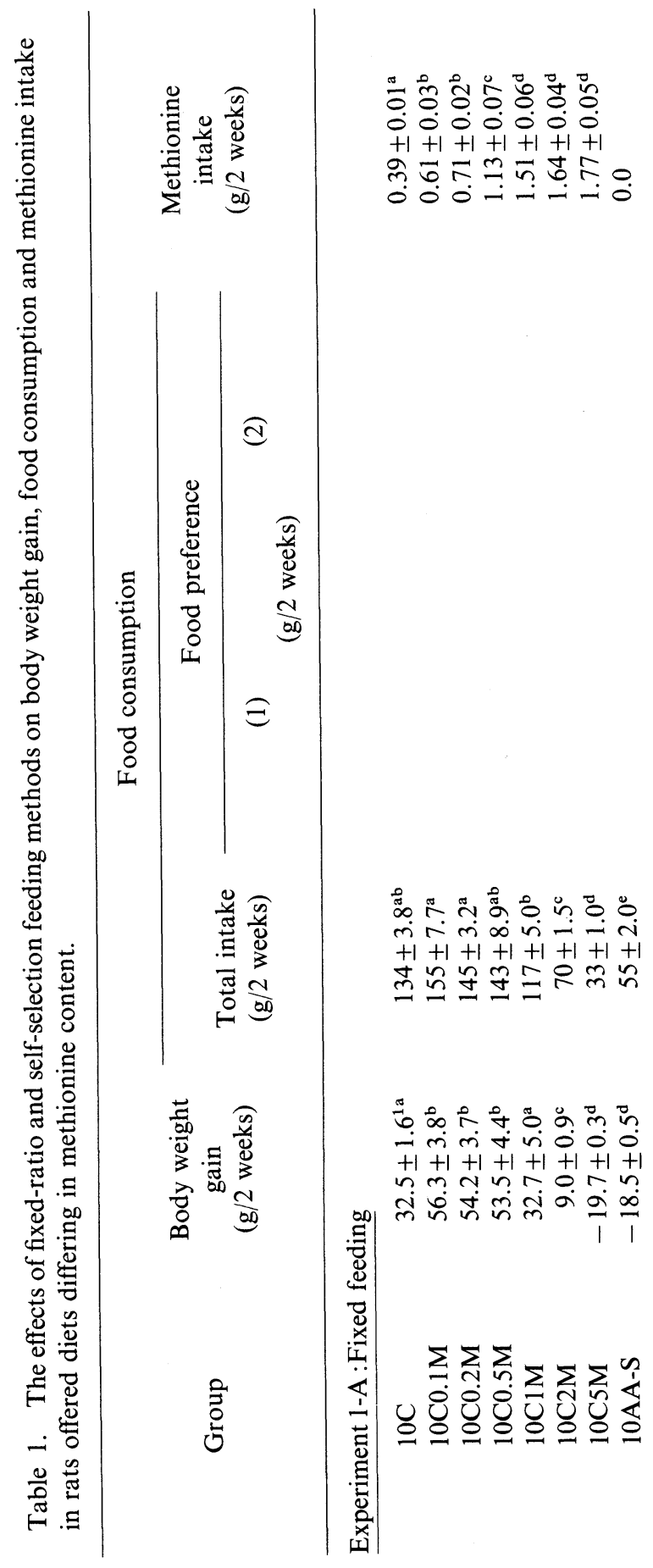

J. Nutr. Sci. Vitaminol. 


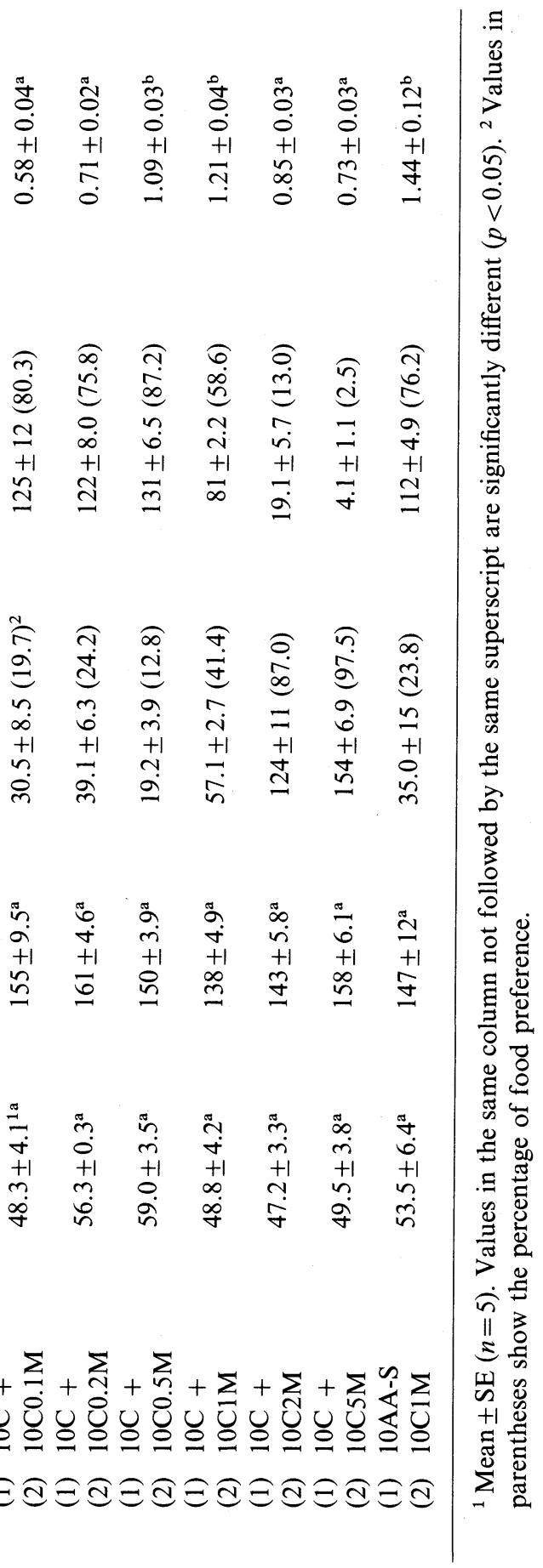

Vol. 28, No. 2, 1982 
were added $(10 \mathrm{C} 0.1 \mathrm{M}, 10 \mathrm{C} 0.2 \mathrm{M}$ and $10 \mathrm{C} 0.5 \mathrm{M})$, but at the addition of methionine above the $1 \%$ level, marked growth depression was caused. The weight loss in animals fed on the $10 \mathrm{C}$ diet with $5 \%$ methionine (10C5M) added was comparable to that in rats fed on the diet lacking methionine and cystine (10AA-S). The food consumption of these groups was about proportional to the weight change, and the rats fed on the $10 \mathrm{C} 5 \mathrm{M}$ or the 10AA-S diet ate considerably less than those fed on the $10 \mathrm{C}$ diet.

When rats were simultaneously offered a choice of two diets which differed in methionine content (Exp. 1-B), weight gain and food consumption of all the combination groups were comparable to those in animals fixed-ratio fed the $10 \mathrm{C} 0.1 \mathrm{M}, 10 \mathrm{C} 0.2 \mathrm{M}$ and $10 \mathrm{C} 0.5 \mathrm{M}$ diets. The rats that were given a choice between the $10 \mathrm{C}$ and the $10 \mathrm{C} 0.1 \mathrm{M}, 10 \mathrm{C} 0.2 \mathrm{M}$ or $10 \mathrm{C} 0.5 \mathrm{M}$ diets ate greater amounts of the diets with added methionine than of the $10 \mathrm{C}$ diet, and to the same extent with selected amounts of the $10 \mathrm{C} 0.1 \mathrm{M}, 10 \mathrm{C} 0.2 \mathrm{M}$ and $10 \mathrm{C} 0.5 \mathrm{M}$ diets $(80.3,75.8$ and 87.2 , respectively). Rats given a choice between the $10 \mathrm{C}$ and the $10 \mathrm{C} 1 \mathrm{M}, 10 \mathrm{C} 2 \mathrm{M}$ or $10 \mathrm{C} 5 \mathrm{M}$ diets consumed considerably less of the diet containing methionine as the methionine level increased, and the selected amounts of the $10 \mathrm{C} 1 \mathrm{M}, 10 \mathrm{C} 2 \mathrm{M}$ and $10 \mathrm{C} 5 \mathrm{M}$ diets were $58.6,13.0$ and $2.5 \%$ of the total intake, respectively. When the dietary choice was between the 10AA-S and the 10C1M diets, rats ate more of the latter diet than the former. The preference for the $10 \mathrm{C} 1 \mathrm{M}$ diet in rats fed on the combination diets of the $10 \mathrm{C} 1 \mathrm{M}$ and 10AA-S was higher than that in animals fed on the $10 \mathrm{C} 1 \mathrm{M}$ and $10 \mathrm{C}$ diets. Methionine intake in the self-selecting rats of this experiment ranged from 0.58 to $1.44 \mathrm{~g}$ per 2 weeks.

Figure 1 shows that rats have the ability to discriminate between diets containing methionine from the beginning of the self-selection experiment, e.g. animals clearly preferred the diets containing $0.1,0.2$ and $0.5 \%$ methionine over the $10 \mathrm{C}$ diet from the first day, while the amounts of the $10 \mathrm{C} 2 \mathrm{M}$ and $10 \mathrm{C} 5 \mathrm{M}$ diets selected were considerably less throughout the experimental period.

\section{Experiment 2}

The effects of fixed-ratio and selection feeding methods on weight gain, food consumption and lysine intake in rats offered diets which differed in lysine content are presented in Table 2, and the dialy food preferences of two diets are shown in Fig. 2.

When rats were fed on the fixed-ratio diet (Exp. 2-A), the addition of $1 \%$ lysine to the $10 \mathrm{C}$ diet did not affect the weight gain and food consumption, but addition of lysine up to a level of $3 \%$ or more caused the depression of growth and food intake. Weight gains of the 10C3L, 10C5L and 10C7L groups were $71.1,44.4$ and $19.4 \%$ that of the $10 \mathrm{C}$ group, respectively. The lysine-devoid group (10AA-L) was unable to maintain the initial body weight. The food consumption of these groups was also roughly proportional to the weight gain.

When rats were offered a choice between the $10 \mathrm{C}$ and the $10 \mathrm{C} 1 \mathrm{~L}, 10 \mathrm{C} 3 \mathrm{~L}$ or $10 \mathrm{C} 7 \mathrm{~L}$ diets, and the $10 \mathrm{AA}-\mathrm{L}$ and the $10 \mathrm{C}, 10 \mathrm{C} 1 \mathrm{~L}$ or $10 \mathrm{C} 5 \mathrm{~L}$ diets (Exp. 2-B), 

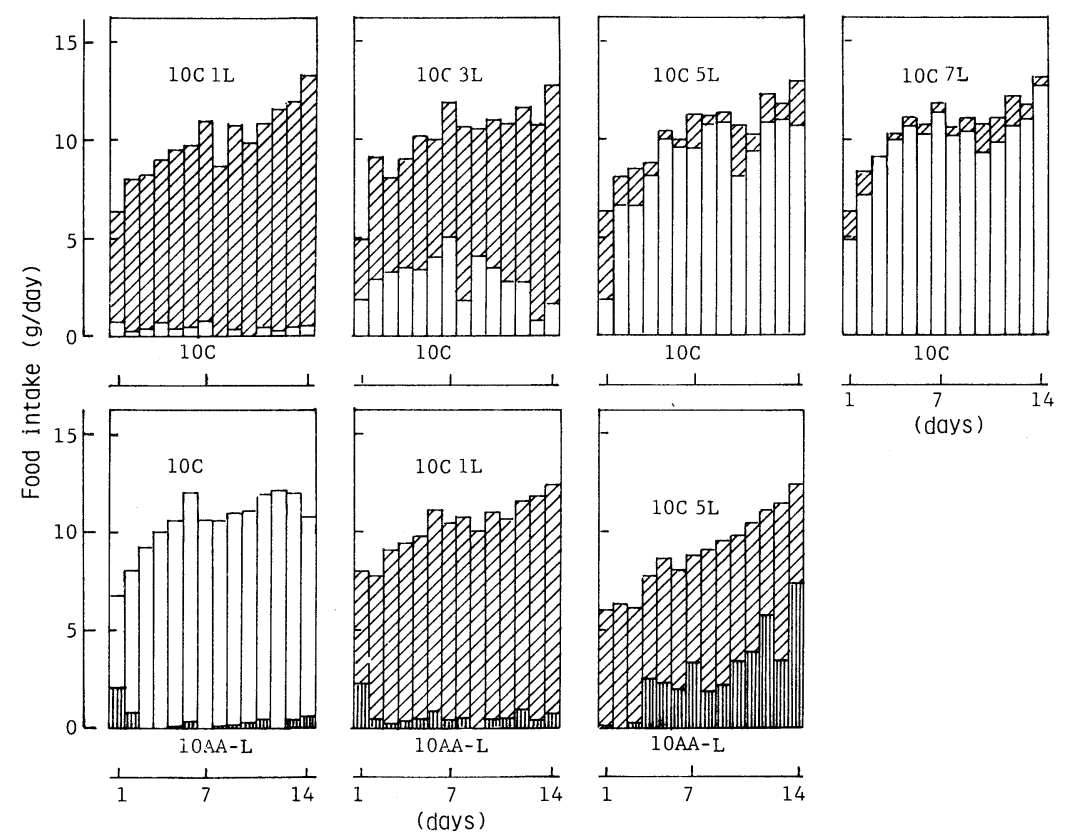

(days)

Fig. 2. Food preference in rats offered a choice of two diets differing in lysine content. Open bars $=10 \mathrm{C}$ group; hatched bars $=10 \mathrm{C} 1 \mathrm{~L}, 10 \mathrm{C} 3 \mathrm{~L}, 10 \mathrm{C} 5 \mathrm{~L}$ or $10 \mathrm{C} 7 \mathrm{~L}$ groups; and vertical-stripe bars $=10 \mathrm{AA}-\mathrm{L}$ group.

weight gain and food consumption of all the combination groups were close to those of the 10C group, except that the weight gain in the combination groups of 10AA-L and 10C5L was somewhat low. When the dietary choices were the 10C and the $10 \mathrm{C} 1 \mathrm{~L}$ or $10 \mathrm{C} 3 \mathrm{~L}$ diets, rats preferred the $10 \mathrm{C} 1 \mathrm{~L}$ and $10 \mathrm{C} 3 \mathrm{~L}$ diets over the $10 \mathrm{C}$ diet, and the amounts consumed were 96.8 and $70.2 \%$ of the total intake, respectively. However, when the lysine level was increased to 5 to $7 \%$, the food preference of both groups was markedly decreased, and the selected amounts were only 14.5 and $6.8 \%$ of the total, respectively. Lysine intake in the self-selecting rats of experiment 2-B ranged from 1.20 to $4.20 \mathrm{~g}$ per 2 weeks.

Figure 2 indicates that rats have the ability to discriminate between diets containing lysine from the start of the experiment, as is the case with methionine, with the exception of the preference for the $10 \mathrm{C} v s .10 \mathrm{C} 5 \mathrm{~L}$, and the $10 \mathrm{C} 5 \mathrm{~L} v s$. $10 \mathrm{AA}-\mathrm{L}$ diets. The selected amount of the 10C5L diet was greater than that of the $10 \mathrm{C}$ diet only on the first day. With the choice between the $10 \mathrm{C} 5 \mathrm{~L}$ and the $10 \mathrm{AA}-\mathrm{L}$ diets, the daily consumption of the latter diet was progressively increased during the feeding period.

Figure 3 shows the relationship between the weight gain and the methionine or lysine intake in rats which were given diets by the fixed-ratio and the self-selection feeding methods. Methionine intakes of self-selecting rats were kept to a relatively 


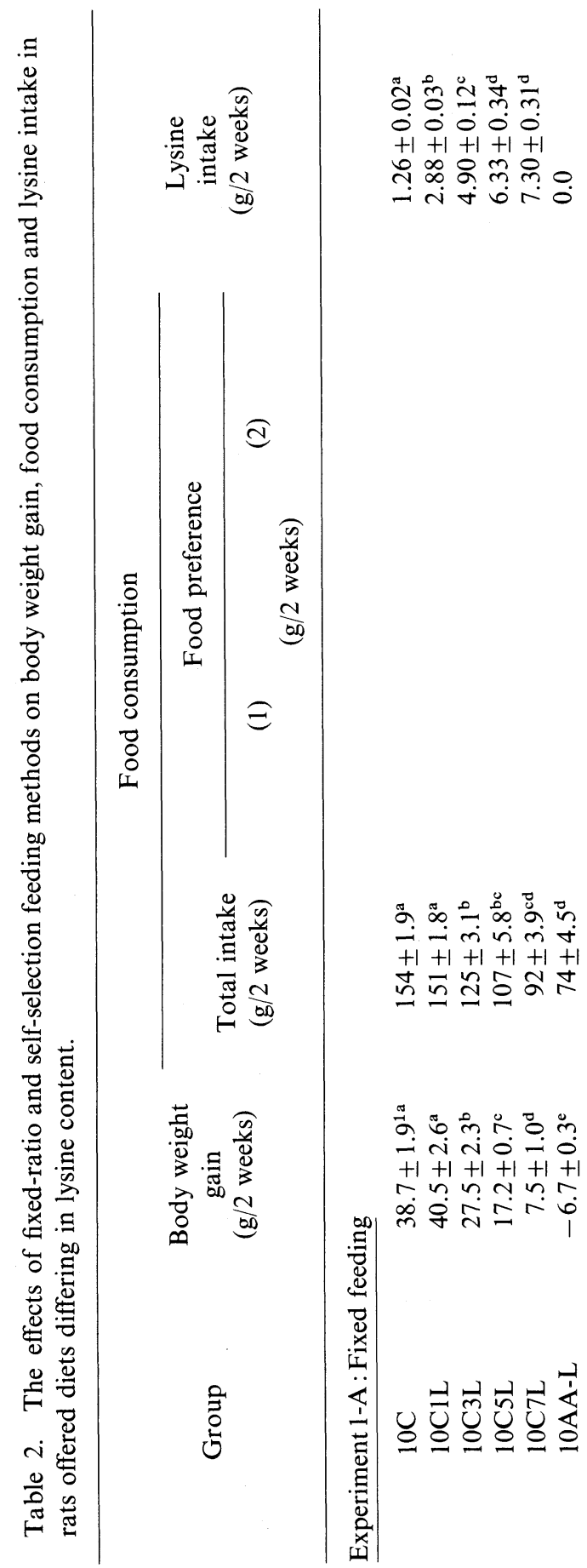




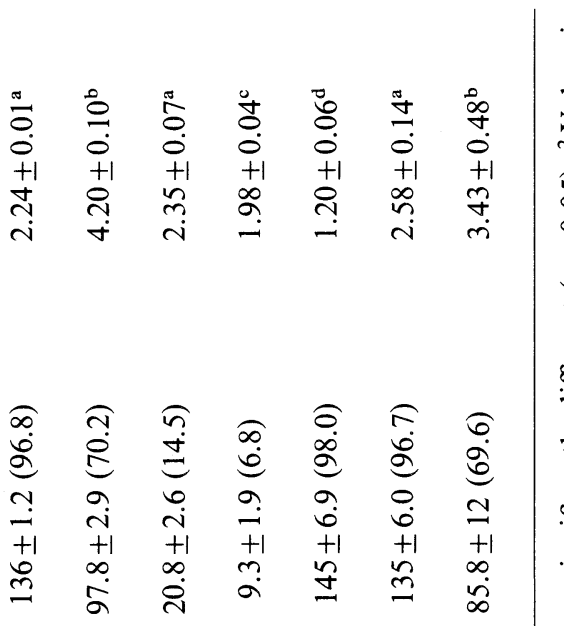

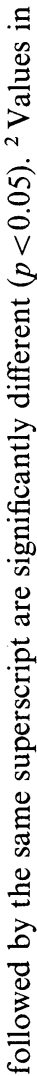

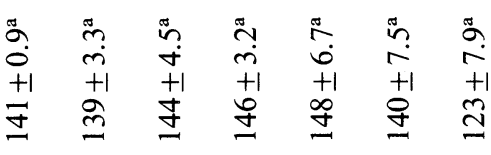

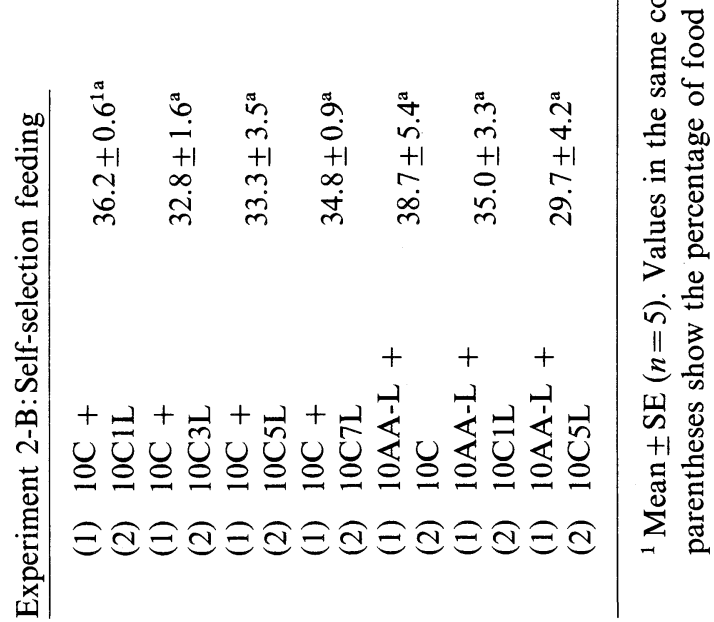

Vol. 28, No. 2, 1982 


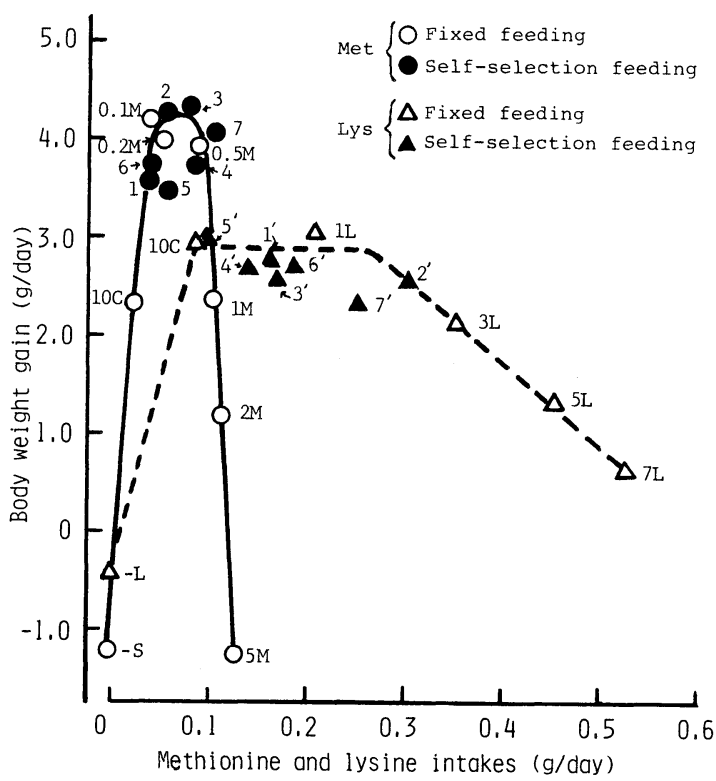

Fig. 3. The relationship between body weight gain and methionine (-) or lysine $(--)$ intake. Symbols within the graph used are: -S, 10AA-S; $0.1 \mathrm{M}, 10 \mathrm{C} 0.1 \mathrm{M}$; $0.2 \mathrm{M}, 10 \mathrm{C} 0.2 \mathrm{M} ; 0.5 \mathrm{M}, 10 \mathrm{C} 0.5 \mathrm{M} ; 1 \mathrm{M}, 10 \mathrm{C} 1 \mathrm{M} ; 2 \mathrm{M}, 10 \mathrm{C} 2 \mathrm{M} ; 5 \mathrm{M}, 10 \mathrm{C} 5 \mathrm{M} ; 1$, $10 \mathrm{C}+10 \mathrm{C} 0.1 \mathrm{M} ; 2, \quad 10 \mathrm{C}+10 \mathrm{C} 0.2 \mathrm{M} ; \quad 3,10 \mathrm{C}+10 \mathrm{C} 0.5 \mathrm{M} ; 4, \quad 10 \mathrm{C}+10 \mathrm{C} 1 \mathrm{M} ; 5$, $10 \mathrm{C}+10 \mathrm{C} 2 \mathrm{M} ; 6,10 \mathrm{C}+10 \mathrm{C} 5 \mathrm{M} ; 7,10 \mathrm{AA}-\mathrm{S}+10 \mathrm{C} 1 \mathrm{M} ;-\mathrm{L}, 10 \mathrm{AA}-\mathrm{L} ; 1 \mathrm{~L}, 10 \mathrm{C} 1 \mathrm{~L} ; 2 \mathrm{~L}$, $10 \mathrm{C} 2 \mathrm{~L} ; 3 \mathrm{~L}, 10 \mathrm{C} 3 \mathrm{~L} ; 5 \mathrm{~L}, 10 \mathrm{C} 5 \mathrm{~L} ; 7 \mathrm{~L}, 10 \mathrm{C} 7 \mathrm{~L} ; 1^{\prime}, 10 \mathrm{C}+10 \mathrm{C} 1 \mathrm{~L} ; 2^{\prime}, 10 \mathrm{C}+10 \mathrm{C} 3 \mathrm{~L} ; 3^{\prime}$, $10 \mathrm{C}+10 \mathrm{C} 5 \mathrm{~L} ; 4^{\prime}, 10 \mathrm{C}+10 \mathrm{C} 7 \mathrm{~L} ; 5^{\prime}, 10 \mathrm{AA}-\mathrm{L}+10 \mathrm{C} ; 6^{\prime}, 10 \mathrm{AA}-\mathrm{L}+10 \mathrm{C} 1 \mathrm{~L} ;$ and $7^{\prime}$, $10 \mathrm{AA}-\mathrm{L}+10 \mathrm{C} 5 \mathrm{~L}$.

narrow range (41-100 mg methionine/day), with weight gains equal to those obtained in animals receiving the fixed-ratio diets supplemented with 0.1 to $0.5 \%$ methionine. In contrast, lysine intakes of self-selecting rats covered a wide range (86-300 mg lysine/day), with maximal weight gain obtained. Thus substantial differences were observed between methionine and lysine intakes. The point at which the intake of methionine and lysine reached a plateau was about the same as with the value which indicates the requirement of total sulfur-amino acid $(22,23)$ and lysine (22-26), respectively. The results of lysine selection in the present study were obtained by the feeding of diets containing suboptimal amounts of methionine, but similar findings have also been observed in a self-selecting experiment using gluten diets which are deficient in lysine only (27).

\section{DISCUSSION}

The present results have clearly demonstrated that, in rats offered a choice of two diets varying only in methionine or lysine content, the intakes of both 
methionine and lysine are regulated, and animals feed to meet the requirement for these amino acids. Figure 3 shows that the intake of methionine is more rigidly regulated than that of lysine. This may be related to the findings that an excessive intake of methionine is highly toxic $(1-3)$. On the other hand, the fact that lysine intake covers a wide range may be attributed to the fact that the activity of liver lysine-ketoglutarate reductase involved in lysine catabolism increases adaptively with increasing ingestion of lysine $(28,29)$.

In connection with the present study, it has been demonstrated that rats exhibit a definite ability to regulate protein intake (13-15). Anderson and associates $(13,14)$ have shown that the rat has a capacity to regulate protein intake and that this regulation is mediated under separate control from energy intake, and that there exists a control mechanism which adjusts protein intake to meet requirement for protein. Peng et al. (15) reported that rats are able to select a protein diet which supports maximal growth when proportions of dietary amino acids are balanced.

From our results, it is suggested that the regulation is mediated by a combination of two modes: one which increases the amino acid intake until a certain requirement is met, and another which prevents the excessive intake of amino acid. For the modes controlling protein intake, a similar assumption has been proposed by Musten et al. (13).

The selections of methionine and lysine observed in the present study (Exp. 1-B and 2-B) are difficult to explain on the basis of palatability of the diets even if the effect cannot be disregarded, because rats were able to select adequate amounts of methionine or lysine from diets differing widely in methionine or lysine content. Ashley and Anderson(14) have suggested that, in the self-selection experiments of dietary protein (gluten and casein), the effect of addition of lysine to both gluten and casein is probably due to the nutritional effect, while in contrast, that of additional of methionine may be due to its taste. In the experiment 1-B on methionine addition, when rats were allowed a choice between the 10C1M and the 10AA-S or $10 \mathrm{C}$ diets, the selection of the $10 \mathrm{C} 1 \mathrm{M}$ diet was much more frequent than that with the 10AA-S or 10C diet (Fig. 1). Similar findings were observed in the experiment 2$\mathrm{B}$ in which self-selection of dietary lysine was examined. When the dietary choices were the $10 \mathrm{C} 5 \mathrm{~L}$ and $10 \mathrm{C}$ diets, and the $10 \mathrm{C} 5 \mathrm{~L}$ and $10 \mathrm{AA}-\mathrm{L}$ diets, the selection of the $10 \mathrm{C} 5 \mathrm{~L}$ diet in later dietary combinations was considerably higher than that in former ones (Fig. 2). These results suggest that the selection of methionine or lysine is related to a nutritional effect rather than an effect due to the palatability of the diets in which methionine or lysine is added, if the taste of methionine and lysine is unpleasant.

Some investigations (16-20) have shown that, when the proportions of the dietary amino acids are out of balance such as in the case of amino acid imbalance and antagonism, the rats are unable to select the diet that supports growth. However, it is well known, in general, that a diet of higher nutritive value will be selected over one of poorer nutritive value, all other nutrients being equal (30-34). For example, rats in B-vitamins deficiency preferred the diet containing the 
vitamins $(31,33)$. Rats preferred a diet containing heated soybean meal over diets containing raw soybean (34).

The mechanisms which control the intake of amino acids, methionine and lysine to meet the requirements these of are not clear. The food intake response caused by a dietary excess of individual amino acids, amino acid imbalance or high levels of protein has been shown to be independent of the ventro-medial area of the hypothalamus $(20,35,36)$. Leung and $\operatorname{Rogers}(20,36)$ have suggested that certain prepyriform areas are responsible for an amino acid deficiency or amino acid imbalance, but not for excess amino acid. Other receptors outside the prepyriform must therefore be involved under situations of high levels of individual amino acids, but the precise areas have not as yet been identified.

It is postulated that plasma amino acid levels or patterns may be responsible for the regulation of amino acid intake. Harper et al.(37) have shown that the depression of food intake in rats fed on amino acid-imbalanced or amino aciddeficient diets is linked to changes in the plasma level of the limiting amino acid. Anderson et al. $(38,39)$ have also proposed that the plasma tryptophan/neutral amino acids (phenylalanine, tyrosine, leucine, isoleucine and valine) ratio correlate inversely with the protein intake selected. It will be important to clarify the involvement of plasma amino acids in the regulation of amino acid intake in selfselected rats.

It is concluded from this study that weanling rats, if allowed a choice of diets containing different levels of methionine or lysine, exhibit evidence of a definite ability to select methionine or lysine to meet maximal growth. One would predict that a similar regulation may also be involved in the intake of other amino acids.

\section{REFERENCES}

1) Harper, A. E., Benevenga, N. J., and Wohlhueter, R. M. (1970): Effects of ingestion of disproportionate amounts of amino acids. Physiol. Rev., 50, 428-558.

2) Sauberlich, H. E. (1961): Studies on the toxicity and antagonism of amino acids for weanling rats. J. Nutr., 75, 61-72.

3) Muramatsu, K., Odagiri, H., Morishita, S., and Takeuchi, H. (1971): Effect of excess levels of individual amino acids on growth of rats fed casein diets. J. Nutr., 101, 11171126.

4) Peng, Y., Gubin, J., Harper, A. E., Vavich, M. G., and Kemmerer, A. R. (1973): Food intake regulation: Amino acid toxicity and changes in rat brain and plasma amino acids. J. Nutr., 103, 608-617.

5) Kaufman, N., Klavins, J. V., and Kinney, T. D. (1960): Pancreatic damage induced by excess methionine. Arch. Pathol., 70, 331-337.

6) Stekol, J. A., and Szaran, J. (1962): Pathological effects of excessive methionine in the diet of growing rats. J. Nutr., 77, 81-90.

7) Klavins, J. V., Kinney, T. D., and Kaufman, N. (1963): Histopathologic changes in methionine excess. Arch. Pathol., 75, 661-673.

8) Jones, J. D., Wolters, R., and Burnett, C. (1966): Lysine-arginine-electrolyte relationships in the rat. J. Nutr., 89, 171--188.

9) Muramatsu, K., and Takada, R. (1978): Adaptive response of liver and kidney lysine- 
ketoglutarate reductase in rats fed dietary lysine and protein. Res. Comm. Essent. Amino Acids (Japan), 78, 23-26.

10) Osborne, T. B., and Mendel, L. B. (1918): The choice between adequate and inadequate diets, as made by rats. J. Biol. Chem., 35, 19-27.

11) Pol, G., and den Hartog, C. (1966): The dependence on protein to caloric ratio in a freely selected diet and the usefulness of giving protein and calories separately in protein evaluation experiments. Brit. J. Nutr., 20, 649-661.

12) Collier, G., Leshner, A. I., and Squibb, R. L. (1969): Self-selection of natural and purified dietary protein. Physiol. Behav., 4, 83-86.

13) Musten, B., Peace, D., and Anderson, G. H. (1974): Food intake regulation in the weanling rat: Self-selection of protein and energy. J. Nutr., 104, 563-572.

14) Ashley, D. V. M., and Anderson, G. H. (1975): Food intake regulation in the weanling rat: Effects of the most limiting essential amino acids of gluten, casein, and zein on the self-selection of protein and energy. J. Nutr., 105, 1405-1411.

15) Peng, Y., Meliza, L. L., Vavich, M. G., and Kemmerer, A. R. (1975): Effects of amino acid imbalance and protein content of diets on food intake and preference of young, adult, and diabetic rats. J. Nutr., 105, 1395-1404.

16) Sanahuja, J. C., and Harper, A. E. (1962): Effect of amino acid imbalance on food intake and preference. Am. J. Physiol., 202, 165-170.

17) Leung, P. M.-B., Rogers, Q. R., and Harper, A. E. (1968): Effect of amino acid imbalance on dietary choice in the rat. J. Nutr., 95, 483-492.

18) Pant, K. C., Rogers, Q. R., and Harper, A. E. (1972): Food selection studies of rats fed tryptophan-imbalanced diets with or without niacin. J. Nutr., 102, 131-142.

19) Rogers, Q. R., Tannous, R. I., and Harper, A. E. (1967): Effects of excess leucine on growth and food selection. J. Nutr., 91, 561-572.

20) Rogers, Q. R., and Leung, P. M.-B. (1973): The influence of amino acids on the neuroregulation of food intake. Fed. Proc., 320, 1709-1719.

21) Muramatsu, K., Arito, T., and Tsuda, H. (1976): Effect of individual amino acid supplements on the toxicity of excess tyrosine in rats. J. Nutr. Sci. Vitaminol., 22, 397403.

22) National Research Council (1972): Nutrient Requirements of Laboratory Animals, Natl. Acad. Sci., Washington, D. C., pp. 56-93.

23) Rama Rao, P. B., Norton, H. W., and Johnson, B. C. (1961): The amino acid composition and nutritive value of proteins. IV. Phenylalanine, tyrosine, methionine and cystine requirements of the growing rat. J. Nutr., 73, 38-42.

24) Williams, H. H., Courtin, L. V., Abraham, J., Loosli, J. K., and Maynard, L. A. (1954): Estimation of growth requirements for amino acids by assay of the carcass. J. Biol. Chem., 208, 277-286.

25) Calhoun, W. K., Hepburn, F. N., and Bradley, W. B. (1960): The availability of lysine in wheat, flour, bread and gluten. J. Nutr., 70, 337-347.

26) Morrison, A. B., Middleton, E. J., and McLaughlan, J. M. (1961): Blood amino acid studies. II. Effects of dietary lysine concentration, sex, and growth rate on plasma free lysine and threonine levels in the rat. Can. J. Biochem. Physiol., 39, 1675-1680.

27) Muramatsu, K., and Ohya, M. (1980): Self-selection of dietary lysine in the rat. Rep. Res. Comm. Essent. Amino Acids (Japan), 88, 3-6.

28) Muramatsu, K., and Takada, R. (1978): Adaptive response of liver and kidney lysineketoglutarate reductase in rats fed dietary lysine and protein. Rep. Res. Comm. Essent. Amino Acids (Japan), 78, 23-26.

29) Chu, S-H. W., and Hegsted, D. M. (1976): Adaptive response of lysine and threonine

Vol. 28, No. 2, 1982 
degrading enzymes in adult rats. J. Nutr., 106, 1089-1096.

30) Mitchell, H. S., and Mendel, L. B. (1921): Studies in nutrition: the choice between adequate and inadequate diet as made by rats and mice. Am. J. Physiol., 58, 211-225.

31) Harris, L. J., Clay, J., Hargreaves, F., and Ward, A. (1933): Appetite and choice of diet. The ability of the vitamin B deficient rat to discriminate between diets containing and lacking the vitamin. Proc. Roy. Soc. London. (Biol.) 113, 161-190.

32) Richter, C. P., Holt, L. E., and Barelare, B. (1938): Nutritional requirements for normal growth and reproduction in rats studied by the self-selection method. Am. J. Physiol., 112, 734-744.

33) Scott, E. M., and Verney, E. L. (1947): Self selection of diet. VI. The nature of appetites for B vitamins. J. Nutr., 34, 471-480.

34) Naim, M., Kare, M. R., and Ingle, D. E. (1977): Sensory factors which affect the acceptance of raw and heated defatted soybeans by rats. J. Nutr., 107, 1653-1658.

35) Scharrer, E., Baile, C. A., and Mayer, J. (1970): Effect of amino acids and protein on food intake of hyperphagic and recovered aphagia rats. Am. J. Physiol., 218, 400-404.

36) Leung, P. M.-B., and Rogers, Q. R. (1971): Importance of prepyriform cortex in foodintake response of rats to amino acids. Am. J. Physiol., 221, 929-935.

37) Harper, A. E., Leung, P., Yoshida, A., and Rogers, Q. R. (1964): Some new thoughts on amino acid imbalance. Fed. Proc., 23, 1087-1092.

38) Ashley, D. V. M., and Anderson, G. H. (1975): Correlation between the plasma tryptophan to neutral amino acid ratio and protein intake in the self-selecting weanling rat. J. Nutr., 105, 1412-1421.

39) Anderson, G. H., and Ashley, D. V. M. (1977): Correlation of the plasma tyrosine to phenylalanine ratio with energy intake in self-selecting weanling rats. Life Sci., 21, $1227-1233$. 